\title{
Reports
}

In conclusion Prof. H. Martin, in the name of the German Academy of Sciences, presented an invitation to the next regional seismological conference to be held in Jena.

Received 10.5. 1957.

\section{CORRESPONDING MEMBER OF CZECHOSLOVAK ACADEMY OF SCIENCES ALOIS ZATOPEK - STATE PRIZE WINNER}

By decree of the President of the Czechoslovak Republic a Klement Gottwald State Prize for 1957 was awarded to corresponding member of the Czechoslovak Academy of Sciences, Prof. Dr. A. Zátopek, for creating a seismic picture of our state territory, presented in the paper "Seismic Characteristic of Czechoslovakia". A brief biography of Prof. Zátopek was given on the occasion of his election as a corresponding member of the Czechoslovak Academy of Sciences (Čs. čas. fys. $4(1954), 372)$

The honoured work (Sborník Čs. spol.

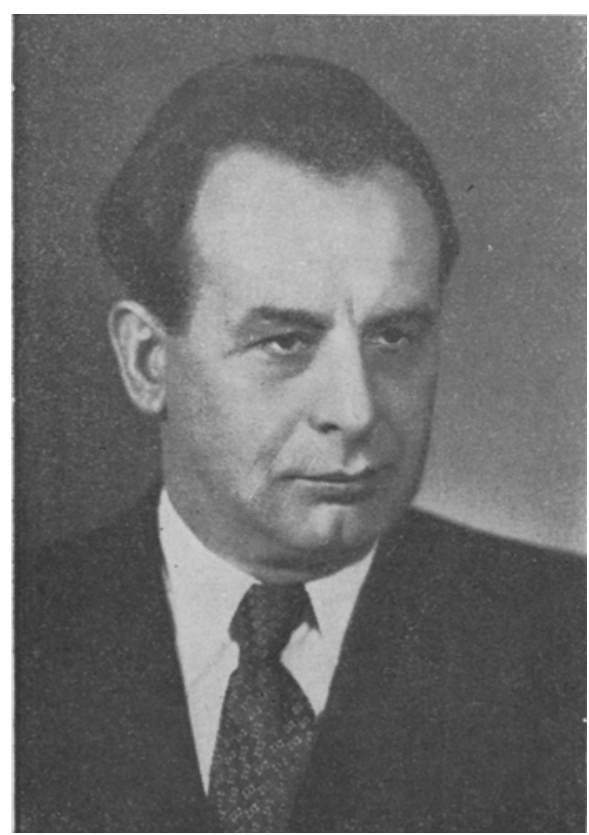
zem. $61(1956), 81)$ is a synthesis of existing surveys on the seismicity of our state and is based to a certain extent on Zátopek's older papers on earthquakes in northern Moravia (Ročenka Stát. ústavu geofys. 3 (1937)), and Slovakia (Publ. Geofys. ústava, Spec. práce 2 (1940), Publ. Bureau Central Séismol. Intern., Travaux scientifiques $A$ 17 (1950), 115 ), as well as on the propagation of the East Alpine earthquakes in the Bohemian Mass (Publ. Stát. ústavu geofys., Spec. práce 3 (1948), Publ. Bureau Central. Séismol. Intern., Travaux scientifiques $A 17(1950), 123)$. It gives the general characteristic of the seismicity of our territory and an analysis of the various regions with increased earthquake activity with particular regard to technical application. The active regions are classified according to the magnitude of the freed energy and their dimensions by means of generalized isoseismal lines. The study ends with a suggestion for further geophysical re. search of seismically activeregions in Czechoslovakia, which is already being realised in the Geophysical Institute of the Czechoslovak Academy of Sciences. The paper is of considerable practical importance for safeguarding large constructions which for various reasons have to be built in the threatened regions. A report was delivered on the paper last year at the session of the European Seismological Commission in Vienna where it aroused considerable interest among specialists in the study of seismicity of the European continent. Thanks to the work of Prof. Zátopek and his collaborators Czechoslovakia today is one of the best studied countries in the field of seismicity.

We heartily congratulate Prof. Zátopek on the great recognition of his work and wish him further success in the future.

Received 20. 5. 1957.

ЧЕ Х ОСЛОВАЦКИЙ ФИЗИЧЕСКИИ ЖУРНАЛ - CZECHOSLOVAK JOURNAL OF PHYSICS Rớnik 7. Vydává Ứstav technické fysiky Ċ SAV v Nakladatelstvi Čs. akademie věd, Praha II, Vodičkova 40, tel. 246-241-8. - Tisknou Pražské tiskárny, n. p., provozovna 05, Praha VIII, tř. Rudé armády 171. Redakce vědeckých časopisù CSAV: Praha II, Vodỉckova 40, tel. 246-241-8. Objednávky přijímá Nakladatelstvi ĆSAV, Praha II, Vodičkova 40. Úcet Státní banky đeskoslovenské císlo 438-214-0087, císlo směrovaci

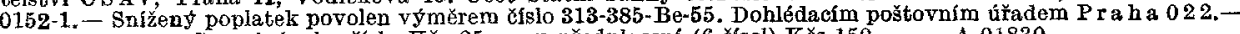

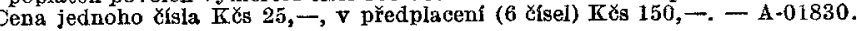
Vyšlo 20.11. 1957. 